\title{
16. CRYSTALLIZATION OF THE CORE 15 BASALT COOLING UNIT, HOLE 396B, DSDP LEG 46
}

\author{
R. James Kirkpatrick, ${ }^{1}$ Scripps Institution of Oceanography, A-031, La Jolla, California \\ and \\ Floyd N. Hodges, Department of Geology, Furman University, Greenville, South Carolina
}

\section{INTRODUCTION}

Hole 396B of Leg 46 of the Glomar Challenger (located at $22^{\circ} 59.14^{\prime} \mathrm{N}, 43^{\circ} 30.90^{\prime} \mathrm{W}$, about $160 \mathrm{~km}$ east of the Mid-Atlantic Ridge) penetrated 205.5 meters into basement and encountered primarily basaltic pillow lava and fragmented material. Only one thick cooling unit was encountered. The purpose of this paper is to describe this cooling unit and discuss its petrographic, mineralogic, and chemical features in terms of its mode of emplacement and the processes occurring during its crystallization.

The cooling unit is sparsely olivine and plagioclase phyric and occupies most of Core 15 (235.0 to $244.5 \mathrm{~m}$ sub-bottom), but because of poor recovery at both margins, neither the top nor the bottom can be identified with complete certainty. If recovery is proportional to actual thickness, the unit is about 9 meters thick. From the top of Core 15 to about $36 \mathrm{~cm}$, the rock is sparsely phyric pillow basalt, which is chemically related to the cooling unit (Leg 46 Scientific Party, this volume). The top of the cooling unit may be the glassy zone at about $36 \mathrm{~cm}$ (Section 15-1, piece 6), but this may also be just another pillow rind. From $36 \mathrm{~cm}$ to $80 \mathrm{~cm}$, the material recovered is fragments up to $10 \mathrm{~cm}$ long which cannot be fit back together. The highest piece examined is Section $15-1$, piece $11(86 \mathrm{~cm})$. This piece clearly belongs to the cooling unit. From $80 \mathrm{~cm}$ to $600 \mathrm{~cm}$ recovery is almost continuous, the pieces can be fit back together well, and the textural variation can be seen clearly in hand specimen and thin section. From $600 \mathrm{~cm}$ to $700 \mathrm{~cm}$ recovery is again fragmentary, but the textural variation appears to continue. We will assume that the lowest sparsely phyric piece is the base of the cooling unit, but because of the incomplete recovery, we will simply plot data versus position in Core 15 . Below $700 \mathrm{~cm}$ the rock is porphyritic pillow basalt chemically unrelated to the cooling unit and with a different magnetic inclination (Leg 46 Scientific Party, this volume). The contact was not recovered.

We will show that the cooling unit must be a lava flow or shallow sill, that the olivine and plagioclase compositions are consistent with some settling of these two phases during crystallization, that the variation of plagioclase grain size and the spacing of the arms of skeletal plagioclase crystals is consistent with a simple cooling history in the temperature range where plagioclase first crystallized, and that some disturbance in the cooling history of the center part of the unit occurred after plagioclase started crystallizing there but before clinopyroxene did.

${ }^{1}$ Present address: Department of Geology, University of Illinois, Urbana, Illinois.

\section{PETROGRAPHY, MINERALOGY, AND CHEMISTRY}

The basalt of the cooling unit is normal oceanic tholeiite with less than 1 per cent olivine and plagioclase phenocrysts (Leg 46 Scientific Party, this volume). The groundmass phases are olivine, plagioclase, clinopyroxene, titanomagnetite, ilmenite, and a variety of alteration minerals including calcite, smectites, and zeolites (Honnorez et al., this volume). the texture varies from essentially holocrystalline intergranular to hypocrystalline intersertal (or even hyalopoikilitic if Section 15-1, piece 6 is a flow top) at the margin.

\section{Major Element Chemistry}

Major element analyses of rocks from the cooling unit have been performed onboard Glomar Challenger (Leg 46 Scientific Party, this volume) and by several groups after the cruise (Dungan et al.; Flower et al.; Mevel et al.; Sato et al.; all this volume). We will use the shipboard analyses and those of Dungan et al.

$\mathrm{MgO}, \mathrm{FeO}^{*} / \mathrm{FeO} *+\mathrm{MgO}$, and $\mathrm{CaO} / \mathrm{CaO}+\mathrm{Na}_{2} \mathrm{O}$ are plotted versus position in Core 15 in Figure 1. The dramatic
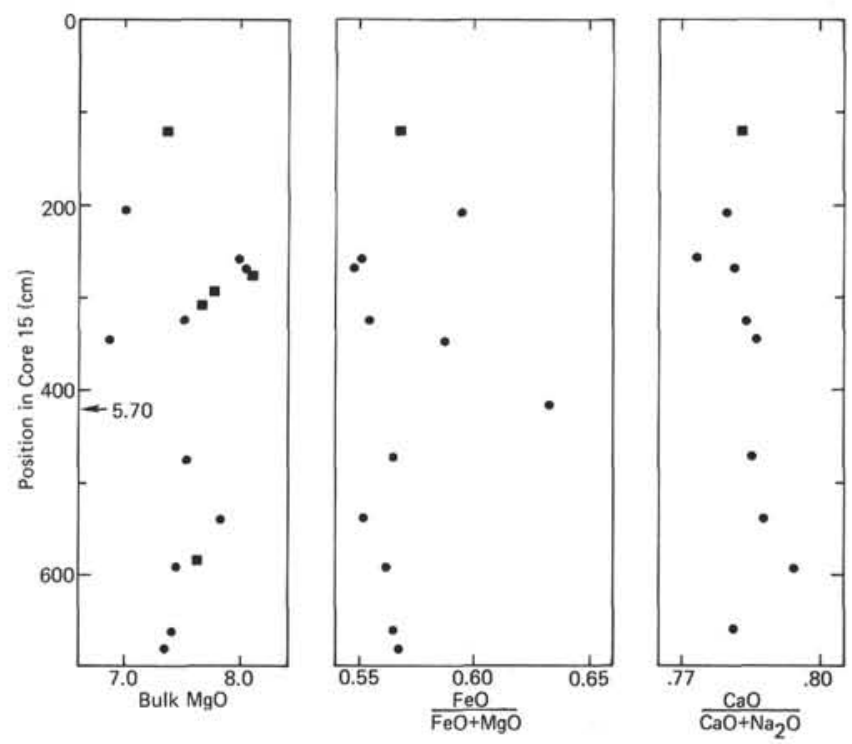

Figure 1. Bulk $\mathrm{MgO}, \mathrm{FeO} / \mathrm{FeO}+\mathrm{MgO}$, and $\mathrm{CaO} / \mathrm{CaO}+$ $\mathrm{Na}_{2} \mathrm{O}$ versus position in the Core 15 cooling unit. The low $\mathrm{MgO}$ and high $\mathrm{FeO} * / \mathrm{FeO}^{*}+\mathrm{MgO}$ values in the center of the cooling unit are probably due to alteration. Squares are shipboard analyses, circles those of Dungan et al. 
drop in $\mathrm{MgO}$ and increase in $\mathrm{FeO} * / \mathrm{FeO}^{*}+\mathrm{MgO}$ in the center of the unit are almost certainly due to loss of $\mathrm{MgO}$ during the extensive alteration of this part of the unit. In the lower, relatively unaltered part of the unit, however, $\mathrm{MgO}$ appears to increase and $\mathrm{FeO} * / \mathrm{FeO}^{*}+\mathrm{MgO}$ appears to decrease upward. In the upper part of the unit $\mathrm{MgO}$ may be less and $\mathrm{FeO}^{*} / \mathrm{FeO}^{*}+\mathrm{MgO}$ may be greater than in the other unaltered parts of the unit. $\mathrm{CaO} / \mathrm{CaO}+\mathrm{Na}_{2} \mathrm{O}$ appears to be slightly lower in the upper part of the unit and higher in the lower part of the unit.

\section{Mineral Compositions}

Representative analyses of groundmass olivine, plagioclase, and clinopyroxene are presented in Tables 1, 2, and 3 , respectively. The analyses were obtained using the automated MAC electron microprobe at the California Institute of Technology.

Figure 2 presents mole per cent anorthite in plagioclase, mole per cent forsterite in olivine, and mole per cent
$\mathrm{Al} / \mathrm{Al}+\mathrm{Ti}+\mathrm{Cr} / \mathrm{Ti} / \mathrm{Al}+\mathrm{Ti}+\mathrm{Cr}$ in clinopyroxene versus position in Core 15. The variation in the most forsteritic olivine and most anorthitic plagioclase in each sample is relatively small, about 4 absolute per cent, but is the same for both phases. It is therefore most likely real and not analytical error. In general, olivine is more forsteritic and plagioclase more anorthitic in the lower part of the unit. These data, along with the bulk chemical data, are consistent with some settling of early formed olivine and plagioclase to the bottom part of the unit. The clinopyroxene is more aluminous in the central part of the flow than at the margins, except for Section $15-3$, piece $3 B$, from the very center, which is similar to the marginal samples.

\section{Grain Size, Modes, and Crystal Morphology}

Figure 3 presents the maximum observed plagioclase grain size perpendicular to $(010)$ versus position in Core 15 . As expected from observations in other bodies (reviewed by Walker et al., 1976b), the grain size increases inward from

TABLE 1

Representative Electron Microprobe Analyses of Olivine From the Core 15 Cooling Unit

\begin{tabular}{|c|c|c|c|c|c|c|c|c|c|}
\hline & $\begin{array}{c}15-1, \\
86-89 \mathrm{~cm}\end{array}$ & $\begin{array}{c}15-1, \\
145-148 \mathrm{~cm}\end{array}$ & $\begin{array}{c}15-1, \\
145-148 \mathrm{~cm}\end{array}$ & $\begin{array}{c}15-2, \\
82-87 \mathrm{~cm}\end{array}$ & $\begin{array}{c}15-3, \\
94-100 \mathrm{~cm}\end{array}$ & $\begin{array}{c}15-4, \\
40-43 \mathrm{~cm}\end{array}$ & $\begin{array}{c}15-4 \\
124-130 \mathrm{~cm}\end{array}$ & $\begin{array}{c}15-5, \\
44-48 \mathrm{~cm}\end{array}$ & $\begin{array}{c}15-5, \\
92-99 \mathrm{~cm}\end{array}$ \\
\hline $\mathrm{Mg} 0$ & 44.94 & 44.60 & 43.93 & 42.93 & 42.30 & 45.24 & 43.84 & 45.34 & 44.58 \\
\hline $\mathrm{A}_{2}{ }_{2}{ }_{3}$ & 0.08 & 0.00 & 0.00 & 0.28 & 0.00 & 0.00 & 0.00 & 0.00 & 0.00 \\
\hline $\mathrm{SiO}_{2}$ & 39.37 & 39.49 & 38.65 & 39.20 & 38.60 & 39.37 & 39.46 & 39.03 & 39.73 \\
\hline $\mathrm{Ca} 0$ & 0.32 & 0.32 & 0.29 & 0.37 & 0.33 & 0.26 & 0.32 & 0.30 & 0.31 \\
\hline $\mathrm{TiO}_{2}$ & 0.05 & 0.00 & 0.03 & 0.00 & 0.02 & 0.00 & 0.00 & 0.00 & 0.00 \\
\hline $\mathrm{Cr}_{2} \mathrm{O}_{3}$ & 0.08 & 0.11 & 0.10 & 0.00 & 0.04 & 0.11 & 0.06 & 0.00 & 0.00 \\
\hline Mn0 & 0.25 & 0.23 & 0.24 & 0.31 & 0.31 & 0.19 & 0.34 & 0.18 & 0.24 \\
\hline $\mathrm{Fe} 0$ & 16.23 & 15.49 & 15.89 & 18.66 & 17.63 & 14.96 & 17.21 & 15.97 & 15.38 \\
\hline $\mathrm{NiO}$ & 0.20 & 0.29 & 0.17 & 0.17 & 0.18 & 0.19 & 0.10 & 0.15 & 0.17 \\
\hline Total & 101.52 & 101.52 & 99.30 & 101.92 & 99.44 & 100.32 & 101.33 & 100.97 & 100.43 \\
\hline Fo & 82.9 & 83.5 & 82.9 & 80.1 & 80.8 & 84.2 & 81.7 & 83.3 & 83.6 \\
\hline $\mathrm{Fa}$ & 17.1 & 16.5 & 17.1 & 19.9 & 19.2 & 15.8 & 18.3 & 16.7 & 16.4 \\
\hline
\end{tabular}

TABLE 2

Representative Electron Microprobe Analyses of Plagioclase From the Core 15 Cooling Unit

\begin{tabular}{|c|c|c|c|c|c|c|c|c|c|c|c|}
\hline & $\begin{array}{c}15-1, \\
86-89 \mathrm{~cm}\end{array}$ & $\begin{array}{c}15-1, \\
145-148 \mathrm{~cm}\end{array}$ & $\begin{array}{c}15-2, \\
82-87 \mathrm{~cm}\end{array}$ & $\begin{array}{c}15-2, \\
82-87 \mathrm{~cm}\end{array}$ & $\begin{array}{c}15-3, \\
50-54 \mathrm{~cm}\end{array}$ & $\begin{array}{c}15-3, \\
146-149 \mathrm{~cm}\end{array}$ & $\begin{array}{c}15-3 \\
146-149 \mathrm{~cm}\end{array}$ & $\begin{array}{c}15-4, \\
40-42 \mathrm{~cm}\end{array}$ & $\begin{array}{c}15-4, \\
124-130 \mathrm{~cm}\end{array}$ & $\begin{array}{c}15-5 \\
44-48 \mathrm{~cm}\end{array}$ & $\begin{array}{c}15-5, \\
92-99 \mathrm{~cm}\end{array}$ \\
\hline $\mathrm{Na}_{2} \mathrm{O}$ & 3.57 & 3.90 & 5.87 & 3.87 & 5.50 & 3.90 & 4.49 & 3.60 & 4.02 & 3.67 & 4.03 \\
\hline $\mathrm{Mg0}$ & 0.28 & 1.38 & 0.08 & 0.28 & 0.10 & 0.21 & 0.19 & 0.25 & 0.23 & 0.23 & 0.26 \\
\hline $\mathrm{A}_{2}{ }_{2} \mathrm{O}_{3}$ & 29.90 & 28.23 & 27.42 & 29.52 & 26.90 & 29.14 & 28.36 & 29.52 & 30.50 & 31.24 & 30.20 \\
\hline $\mathrm{SiO}_{2}$ & 52.59 & 53.01 & 56.53 & 52.37 & 56.96 & 51.99 & 53.17 & 50.92 & 51.95 & 51.49 & 52.16 \\
\hline $\mathrm{K}_{2} 0$ & 0.03 & 0.16 & 0.06 & 0.02 & 0.06 & 0.03 & 0.04 & 0.03 & 0.02 & 0.04 & 0.02 \\
\hline $\mathrm{Ca} 0$ & 14.07 & 12.17 & 9.77 & 13.31 & 10.17 & 13.52 & 12.41 & 14.31 & 13.55 & 14.00 & 13.78 \\
\hline $\mathrm{TiO}_{2}$ & 0.00 & 0.14 & 0.11 & 0.10 & 0.31 & 0.13 & 0.15 & 0.00 & 0.53 & 0.08 & 0.07 \\
\hline $\mathrm{FeO}$ & 0.63 & 1.55 & 1.03 & 0.89 & 0.99 & 0.50 & 0.71 & 0.45 & 0.16 & 0.74 & 0.59 \\
\hline Total & 101.07 & 100.54 & 100.88 & 100.36 & 100.99 & 99.42 & 99.52 & 99.08 & 101.06 & 101.19 & 101.11 \\
\hline An & 69.4 & 62.7 & 47.7 & 65.5 & 50.3 & 65.6 & 60.3 & 68.6 & 65.0 & 67.7 & 65.3 \\
\hline $\mathrm{Ab}$ & 31.4 & 36.4 & 51.9 & 34.4 & 49.3 & 34.2 & 39.5 & 31.2 & 34.9 & 32.1 & 34.6 \\
\hline Or & 0.2 & 0.9 & 0.4 & 0.1 & 0.4 & 0.2 & 0.2 & 0.2 & 0.1 & 0.2 & 0.1 \\
\hline
\end{tabular}


TABLE 3

Representative Electron Microprobe Analyses of Clinopyroxene From the Core 15 Cooling Unit

\begin{tabular}{|c|c|c|c|c|c|c|c|c|c|c|c|}
\hline & $\begin{array}{c}15-1 \\
86-89 \mathrm{~cm}\end{array}$ & $\begin{array}{c}15-1 \\
145-148 \mathrm{~cm}\end{array}$ & $\begin{array}{c}15-2, \\
82-87 \mathrm{~cm}\end{array}$ & $\begin{array}{c}15-3 \\
50-54 \mathrm{~cm}\end{array}$ & $\begin{array}{l}15-3, \\
94-100 \mathrm{~cm}\end{array}$ & $\begin{array}{c}15-3 \\
146-149 \mathrm{~cm}\end{array}$ & $\begin{array}{c}15-4 \\
40-43 \mathrm{~cm}\end{array}$ & $\begin{array}{c}15-4 \\
40-43 \mathrm{~cm}\end{array}$ & $\begin{array}{c}15-4 \\
124-130 \mathrm{~cm}\end{array}$ & $\begin{array}{c}15-5 \\
44-48 \mathrm{~cm}\end{array}$ & $\begin{array}{c}15-5, \\
92-99 \mathrm{~cm}\end{array}$ \\
\hline $\mathrm{Na}_{2} \mathrm{O}$ & 0.64 & 0.44 & 0.35 & 0.32 & 0.38 & 0.35 & 0.43 & 0.45 & 0.47 & 0.52 & 0.49 \\
\hline $\mathrm{Mg} 0$ & 11.69 & 12.09 & 13.64 & 14.73 & 13.69 & 14.26 & 13.55 & 8.99 & 13.22 & 11.77 & 12.32 \\
\hline $\mathrm{Al}_{2} \mathrm{O}_{3}$ & 6.33 & 5.19 & 3.06 & 5.03 & 4.07 & 5.71 & 4.67 & 2.65 & 4.33 & 6.02 & 4.87 \\
\hline $\mathrm{SiO}_{2}$ & 46.33 & 47.21 & 49.07 & 49.54 & 48.92 & 48.13 & 48.10 & 49.56 & 48.91 & 47.00 & 47.58 \\
\hline $\mathrm{CaO}$ & 21.94 & 20.69 & 17.68 & 19.91 & 20.08 & 21.32 & 20.88 & 18.42 & 20.65 & 21.15 & 20.04 \\
\hline $\mathrm{Ti}_{2}$ & 4.10 & 2.38 & 1.65 & 1.55 & 1.83 & 1.66 & 1.97 & 1.90 & 1.82 & 2.92 & 2.63 \\
\hline $\mathrm{Cr}_{2} \mathrm{O}_{3}$ & 0.17 & 0.14 & 0.03 & 0.30 & 0.34 & 0.27 & 0.28 & 0.00 & 0.19 & 0.18 & 0.31 \\
\hline Mn0 & 0.19 & 0.23 & 0.35 & 0.20 & 0.21 & 0.14 & 0.21 & 0.51 & 0.24 & 0.26 & 0.22 \\
\hline $\mathrm{Fe} 0$ & 9.67 & 11.28 & 13.38 & 8.53 & 10.39 & 7.71 & 9.25 & 17.84 & 10.78 & 10.80 & 12.14 \\
\hline Total & 101.06 & 99.65 & 99.21 & 100.11 & 99.91 & 99.55 & 99.34 & 100.32 & 100.61 & 100.62 & 100.60 \\
\hline En & 35.4 & 36.2 & 40.1 & 43.4 & 40.2 & 42.0 & 40.0 & 27.6 & 38.6 & 35.5 & 36.6 \\
\hline Wo & 47.8 & 44.5 & 37.3 & 42.2 & 42.3 & 45.1 & 44.3 & 40.7 & 43.3 & 45.8 & 42.8 \\
\hline Fs & 16.8 & 19.3 & 22.6 & 14.4 & 17.5 & 12.9 & 15.7 & 31.7 & 18.1 & 18.7 & 20.6 \\
\hline $\mathrm{Cr} / \mathrm{Cr}+\mathrm{Al}+\mathrm{Ti}$ & 0.01 & 0.01 & 0.004 & 0.03 & 0.04 & 0.03 & 0.03 & 0.00 & 0.02 & 0.02 & 0.03 \\
\hline $\mathrm{A} 1 / \mathrm{Cr}+\mathrm{Al}+\mathrm{Ti}$ & 0.70 & 0.76 & 0.74 & 0.81 & 0.75 & 0.82 & 0.76 & 0.69 & 0.77 & 0.75 & 0.72 \\
\hline $\mathrm{Ti} / \mathrm{Cr}+\mathrm{Al}+\mathrm{Ti}$ & 0.29 & 0.22 & 0.26 & 0.16 & 0.21 & 0.15 & 0.21 & 0.31 & 0.21 & 0.23 & 0.25 \\
\hline
\end{tabular}
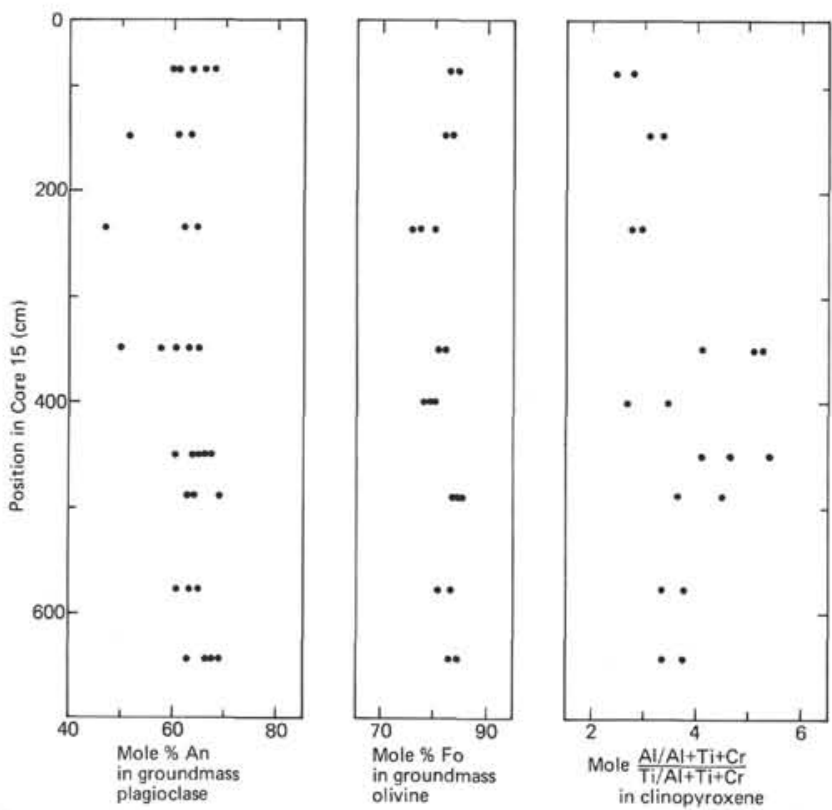

Figure 2. An in plagioclase, Fo in olivine, and $\mathrm{Al} / \mathrm{Al}+\mathrm{Ti}+$ $\mathrm{Cr} / \mathrm{Ti} / \mathrm{Al}+\mathrm{Ti}+\mathrm{Cr}$ in clinopyroxene versus position in the Core 15 cooling unit.

both margins to a maximum near the center of the body. It appears, however, that the maximum size occurs about 100 $\mathrm{cm}$ below the geometrical center of the unit.

Figure 4 presents optically determined modes (over 1000 points per slide) versus position in Core 15 . The difference between the sum of the per cents for all the phases is the amount of unidentifiable, interstitial material, presumably altered glass.

Figure 5 presents the maximum observed spacing between arms or branches of skeletal or dendritic plagioclase and pyroxene crystals and the clinopyroxene/ plagioclase spacing ratio versus position in Core 15. Typical morphologies are illustrated in Plates 1 and 2. Reflected light

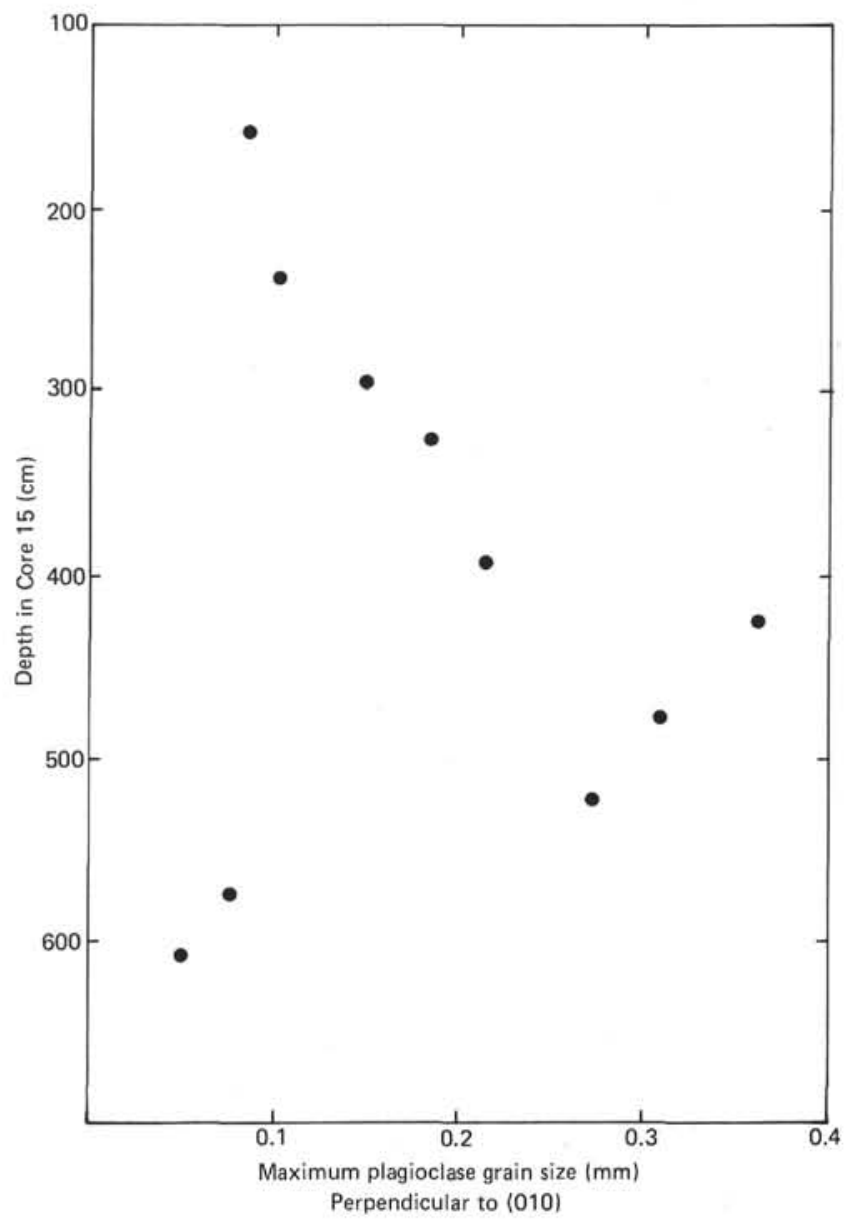

Figure 3. Maximum observed plagioclase grain size perpendicular to (010) versus position in the Core 15 cooling unit.

photographs in Plate 3 illustrate the pyroxene morphologies. The grain with the maximum spacing has been chosen because it can be reasonably inferred (Kirkpatrick, 1977) that 


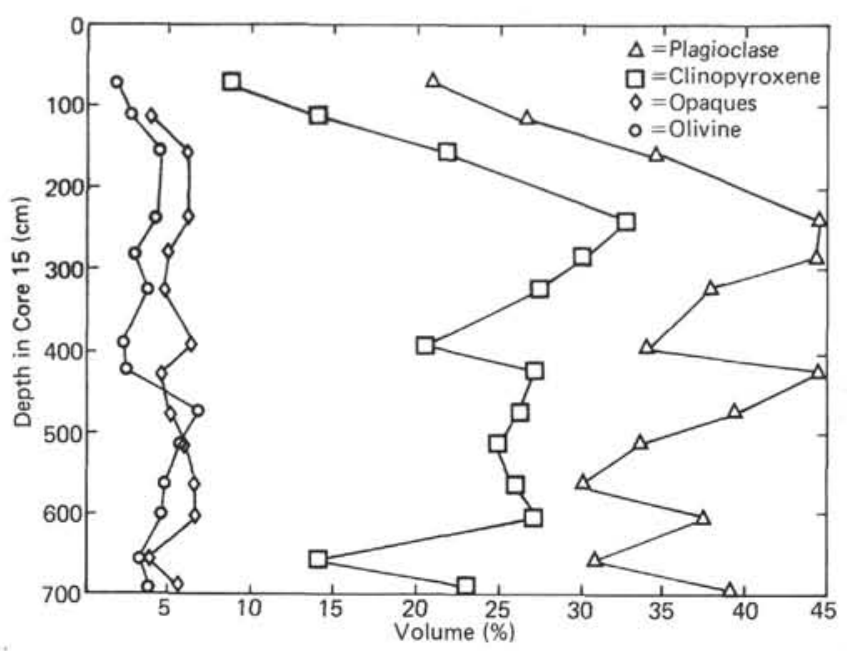

Figure 4. Modal olivine, plagioclase, clinopyroxene, and opaque versus position in the Core 15 cooling unit.
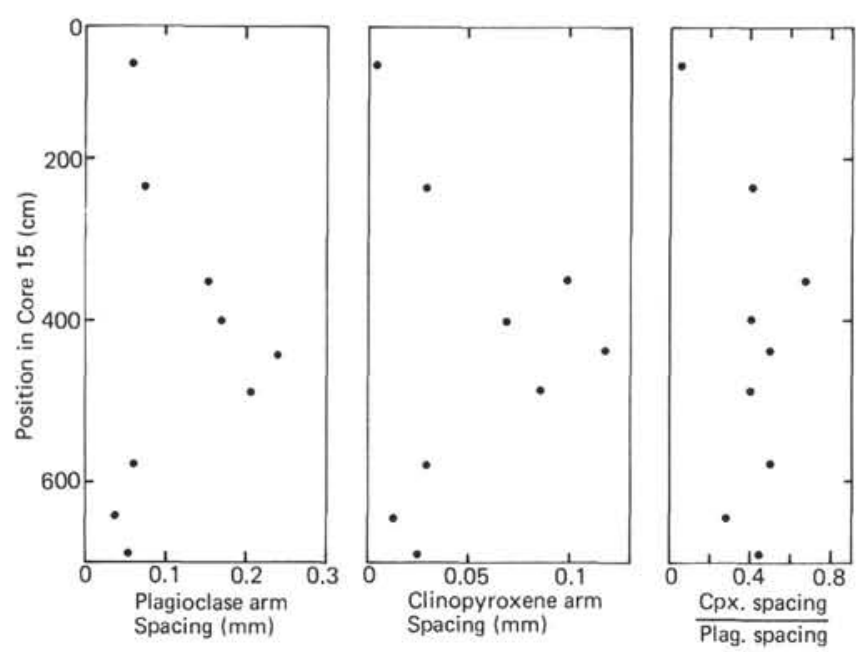

Figure 5. Plagioclase skeleton arm spacing, clinopyroxene skeleton arm spacing, and cpx spacing/plag. spacing versus position in the Core 15 cooling unit.

this was the first grain to nucleate and is the only grain for which the time of nucleation can be inferred, and because it is characteristic of the location in the unit. This spacing is related to the ratio of the rate controlling diffusion coefficient in the melt near the growing crystal to the linear growth rate of the crystal. It decreases with increasing undercooling and increasing cooling rate (Walker et al., 1976a), and is important because it is a measure of how these two factors vary with time and position in a cooling unit.

As with plagioclase grain size, plagioclase spacing increases from the margins of the unit to a maximum about $100 \mathrm{~cm}$ below the center of the unit. Pyroxene spacing behaves in a similar way except that the value in Section $15-3$, piece $3 \mathrm{~B}$, from near the geometrical center of the unit has a lower value than the other samples from the central part of the unit. The pyroxene/plagioclase spacing ratio is relatively constant, except near the top, where it decreases dramatically. There is also a maximum above the geometric center of the unit.

\section{THEORY}

The kinetics of crystallization of igneous bodies has been discussed by Kirkpatrick (1977) and has been briefly reviewed by Kirkpatrick (this volume). It is only necessary to note here that the spacing between arms or branches of skeletal or dendritic crystals is related to the diffusion coefficient/growth rate ratio, and that this ratio decreases with increasing undercooling and therefore increasing cooling rate.

Since some of the petrographic features of this cooling unit are related to cooling rate, and since one of the objectives of this study is to determine whether the unit is a sill or a flow, it is necessary to note the differences in the way cooling rates vary in sills and flows. If a sill is intruded at a depth of 2 or 3 times its thickness, then in the temperature range of solidification the body will cool as if it were infinitely deep, i.e. the surface has no effect on the thermal regime. The highest cooling rates will be at the margins of the body and the slowest at the center, and the cooling will be symmetrical about the center of the body.

In the case of a flow, the top, because of its free upper surface, will cool more rapidly than the bottom. Recent numerical solutions (Walker et al., 1976b; Kirkpatrick et al., in preparation), however, indicate that at temperatures near the emplacement temperature the cooling rates at the top and bottom are comparable, with the value at the top somewhat higher. At temperatures well below the emplacement temperature the insulating effect of the underlying rock becomes important, and the cooling rate near the top becomes much larger than that near the bottom. This causes differences in the positional variation of the undercooling and therefore the crystal morphology between early formed and later formed phases. The early formed phases will have similar spacing near the top and bottom, while the later formed ones will have a much smaller spacing at the top. In addition, for a flow the slowest cooling rate will not occur at the center of the unit, but somewhat below.

If a sill is intruded at a depth less than 2 or 3 times its thickness, the cooling regime will be between that for deep sills and flows and will become more flow like as the cover becomes thinner.

\section{DISCUSSION}

\section{Flow or Sill}

It is clear from the petrographic variation within the unit and the theoretical factors just discussed that the Core 15 cooling unit has had a fairly simple asymmetric cooling history and that there was only one cooling event (no multiple intrusions, for instance). The plagioclase grain size variation is continuous, which would not be expected in a multiple cooling event, and the plagioclase and pyroxene dendrite or skeleton spacing variation has the asymmetry expected of a flow or shallow sill. The slowest cooling rate (largest spacing and grain size) apparently occurred about 
$100 \mathrm{~cm}$ below the geometrical center of the unit. In addition, the pyroxene/plagioclase spacing ratio is much less near the top of the unit than at the bottom. The plagioclase spacing is about the same at the top and bottom, while the pyroxene spacing is much less at the top. This indicates that by the time pyroxene, the third phase after the olivine and plagioclase to crystallize, was growing the top was already cooling faster than the bottom, just the relationship expected for a body cooling primarily from the top.

In the core the cooling unit occurs above a lithologically different unit (porphyritic pillow basalt) with a different magnetic orientation, but below a pillow unit chemically and lithologically similar to the cooling unit. This pillow unit is about the same thickness as the cooling unit and has the same magnetic orientation. On top of this in a chemically distinct pillow unit five times thicker than the cooling unit. These geologic and chemical relationships seem to allow three possibilities for the origin of the cooling unit: (1) a lava flow over which the chemically similar pillow lavas were extruded, (2) a lava flow on top of which pillows formed as it was emplaced, or (3) a sill intruded at the base of the chemically similar pillows. The last two may be gradational with each other. The cooling unit could not have been intruded in its present position after the second pillow unit above it was extruded because this unit is too thick to allow development of the textural asymmetry. What we can definitely conclude from all the textural, geologic, chemical, and magnetic data is that the emplacement of the cooling unit must have been a near sea floor event most likely associated with the eruption of the overlying pillow lavas.

\section{Pyroxene in Section 15-3, Piece 3B and Speculation on the Role of Volatiles}

The clinopyroxene in Section 15-3, piece 3B, near the center of the unit, has a smaller dendrite spacing and a lower $\mathrm{Al} / \mathrm{Ti}$ ratio than the pyroxene in samples on either side of it, and therefore must have crystallized at a large undercooling and with a higher cooling rate than those samples. The plagioclase skeleton spacing, on the other hand, falls on the expected continuous trend. In any simple cooling or kinetic model for a magma body, this cannot happen. It appears that the system was disturbed at this place between the time plagioclase began crystallizing and the time clinopyroxene began crystallizing. This probably also accounts for the low aluminum in the clinopyroxene (Walker et al., 1976a).
One quite possible explanation is that this was the last place pyroxene was crystallizing and sea water entered the interior of the unit through a cooling crack in the already solidified outer part and chilled the remaining liquid, causing the pyroxene to grow at a larger undercooling.

It is also possible, however, that buildup of volatiles (water and carbon dioxide) in the center of the body was responsible. The volatile content of oceanic tholeiites at eruption is quite low (Delaney-and Meunow, 1976; Eggler, 1973; Langmuir et al., 1977). As crystallization of a large body with impermeable walls occurs, however, these volatiles would be concentrated in the remaining liquid and at some point would form a separate phase. If this separate gas phase built up to a pressure higher than the load pressure and was then suddenly released, say through a cooling crack, the liquid would be rapidly undercooled, causing the pyroxene to grow with a smaller dendrite spacing. This hypothesis also explains the presence of the large empty and calcite filled vugs found in this sample. Most likely the original volatiles were not the cause of the extensive alteration of this part of the unit, since it appears to be normal cold sea water alteration (Honnorez et al., this volume), but simply formed a vesicle and vug network through which water could enter.

\section{REFERENCES}

Delaney, J. R. and Meunow, D., 1976. Volatile content of glassy pillow basalt from the Mid-Atlantic Ridge, GSA Abstracts with Programs, v. 8, p. 832-833.

Eggler, D. H., 1973. Role of $\mathrm{CO}_{2}$ in melting processes in the mantle, Annual Report of the Director Geophysical Laboratory, 1972-1973, p. 457-467.

Kirkpatrick, R. J., 1977. Nucleation and growth of plagioclase, Makaopulih and Alae Lava Lakes, Hawaii, Geol. Soc. Am. Bull., v. 88 , p. $78-84$.

Kirkpatrick, R. J., Walker, D., Darbois, N., and Hays, J. F., in preparation. Processes of crystallization and crystal settling in ultramafic flows, Munro Tp., Ontario.

Langmuir, C. H., Bender, J. F., Bence, A. E., Hanson, G. N., and Taylor, S. R., 1977. Petrogenesis of basalts from the FAMOUS area; Mid-Atlantic Ridge, Earth Planet Sci. Lett., v. 36 , p. $133-156$.

Walker, D., Kirkpatrick, R. J., Longhi, J., and Hays, J. F., 1976a. Crystallization history of Lunar Picnitic Basalt Sample 12002: Phase equilibrium and cooling rate studies, Geol. Soc. Am. Bull., v. 87, p. 646-656.

Walker, D., Kirkpatrick, R. J., and Hays, J. F., 1976 b. Differentiation of a Komatiite Lava (abstract), Am. Geophys. Union Trans., v. 58, p. 527. 
PLATE 1

Textural variation observed in the upper part of the Core 15 cooling unit (plane polarized transmitted light photomicrographs).

Figure 1 Sample $15-1,81-89 \mathrm{~cm}$.

Figure 2 Sample 15-1, 145-148 cm.

Figure 3 Sample $15-2,82-89 \mathrm{~cm}$.

Figure $4 \quad$ Sample $15-3,50-54 \mathrm{~cm}$.

Figure 5 Sample $15-3,94-100 \mathrm{~cm}$.

Figure 6 Sample 15-3, 146-149 cm. 

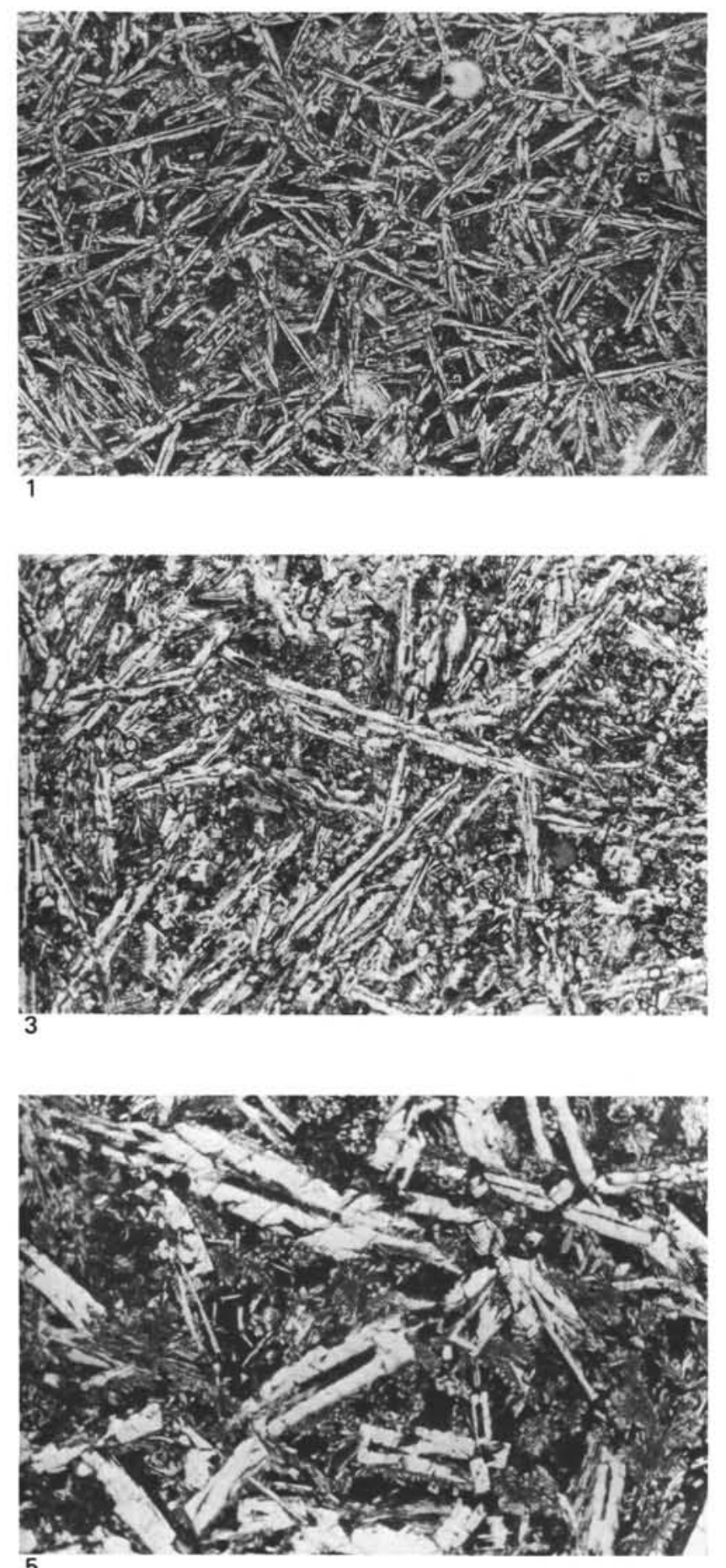
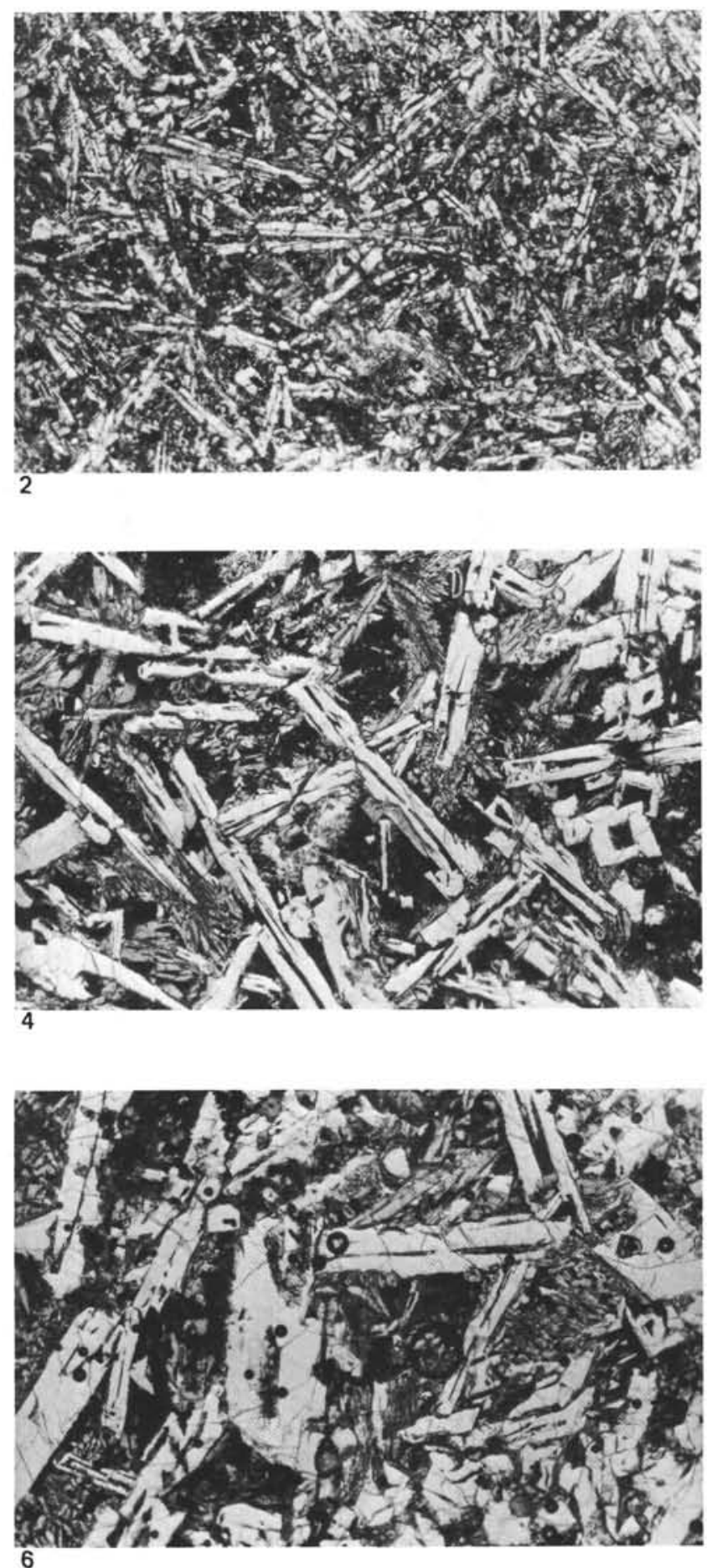
PLATE 2

Textural variation observed in the lower part of the Core 15 unit (plane polarized transmitted light photomicrographs).

Figure $1 \quad$ Sample $15-4,40-43 \mathrm{~cm}$.

Figure 2 Sample $15-4,124-130 \mathrm{~cm}$.

Figure 3 Sample 15-5, 92-94 cm. 
PLATE 2

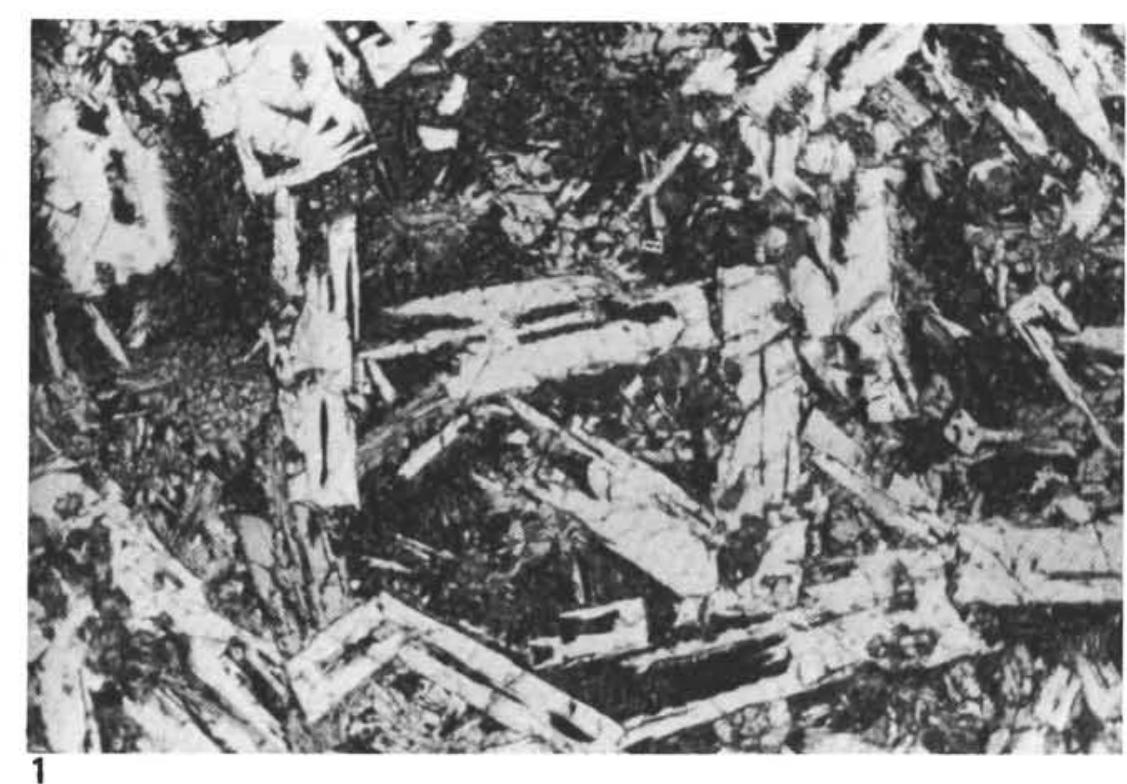

S.

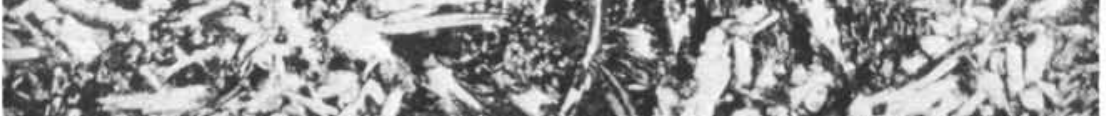

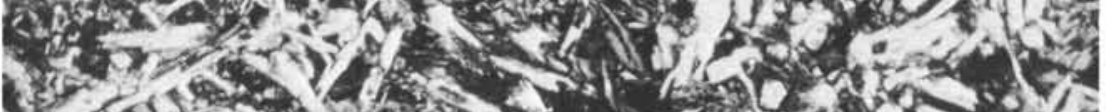

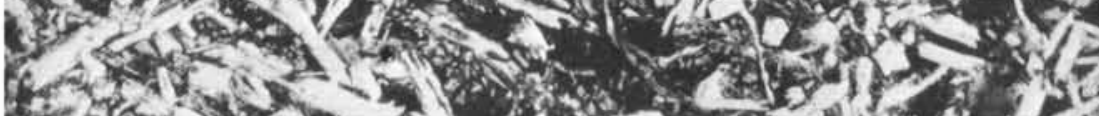

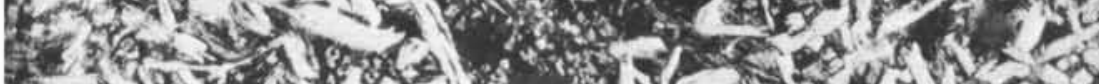

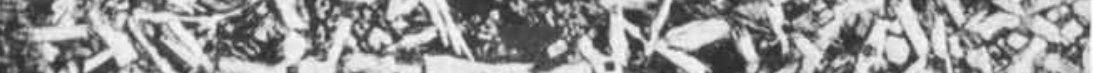

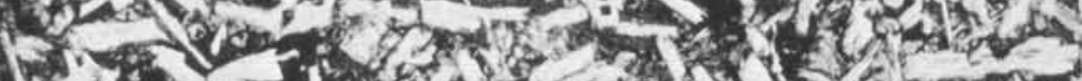

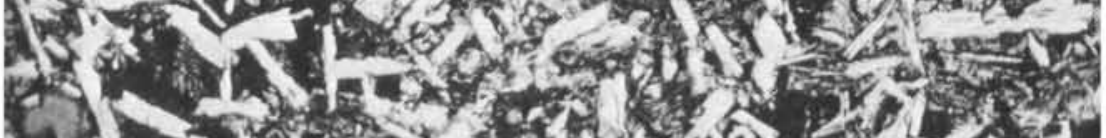

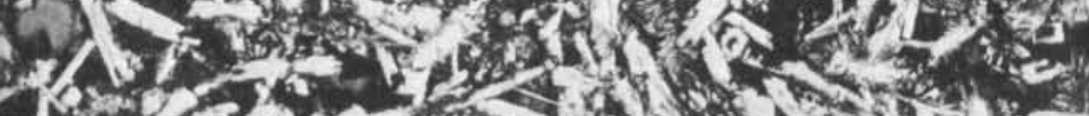

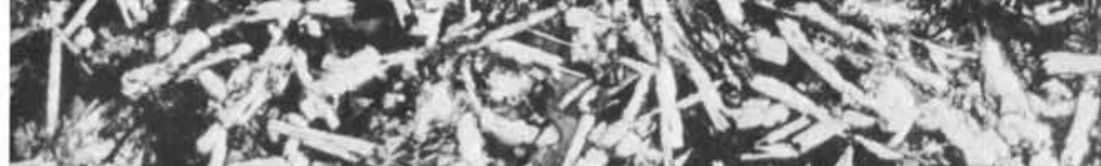

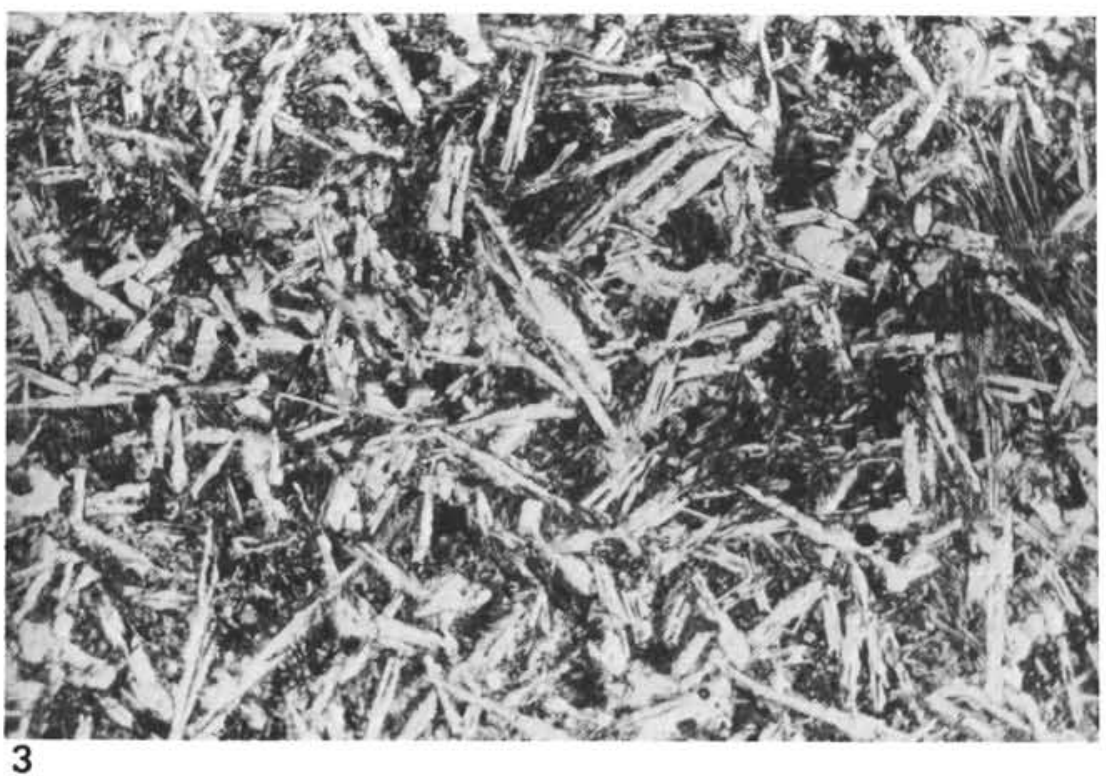


PLATE 3

Reflected light photomicrographs illustrating plagioclase (medium gray) and clinopyroxene (light gray) morphologies in the Core 15 cooling unit. White grains are opaque minerals (titanomagnetite and ilmenite). Mottled areas are altered glass.

Figure 1 Sample $15-4,40-43 \mathrm{~cm}$.

Figure 2 Sample 15-3, $94-100 \mathrm{~cm}$.

Figure 3 Sample 15-4, 124-130 cm. 


\section{PLATE 3}
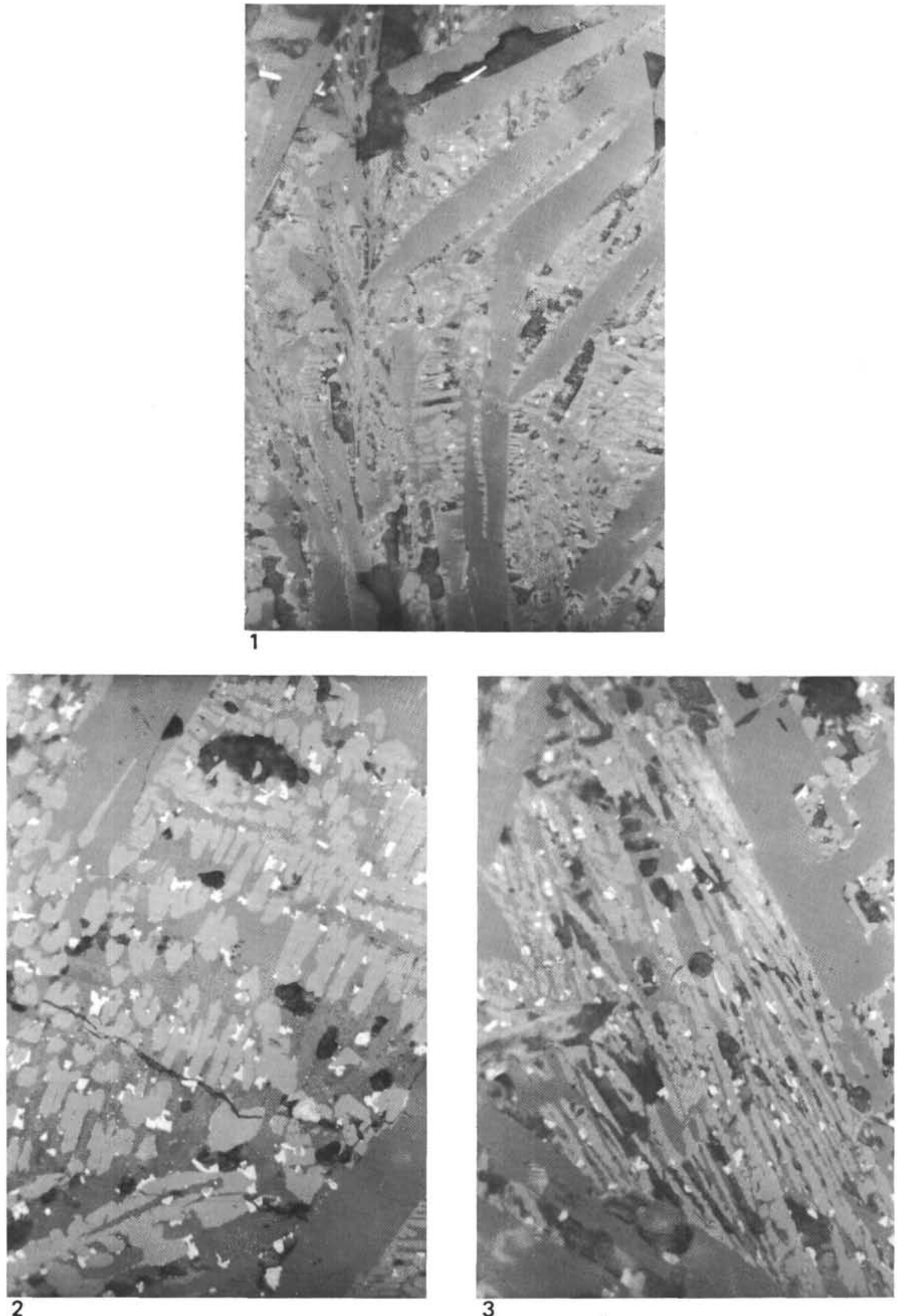